No texto de Alice Fátima Martins (UnB), a autora discute o conceito ae patrimônio cultural imaterial, para pøder tratar do projeto pedagógico das escolas parques de Salvador e Brasília, pensadas por Anísio Teixeira.

A política da reconstrução hacional, orientada pelos princípios de que tal reconstrução se faria pela educação, e o tema destacado por Iria Brzezinski (JCG). A pesquisa sobre o caso do Instjtuto de Educação de Goiás (IEG) foi rea/izada a partir de uma análise documental em fontes primárias, com reconstituições no campo empírico fazendo uso da Histófia oral.

Na Região Nordeste, as pesquisadoras Stela Borges de Alnueida e Joseânea Miranda Freitas (UFBA) ahalisam o legado de Anísio Teixeira na Bahia. A criação de escolas experimentais e demonstrativas para a formação de professores, fundamentadas no princípio o a relação entre ensino e pesquisa no Estado, é destacada. Também são abordados ofextenso programa de construções escolares rurais e urbanas e a instalação da bibliøteca infantil e do CRPE/BA.

Os desdobramentos do programa de Cøoperação Técnica e Financeira das Unidades Federadas no Estado de Sergipe e os seminários organizados pelo Inep, estudos

\section{Da expansão do ensino à fragmentação da educação profissional}

FRIGOTTO, Gaudêncio; CIAVATTA, Maria (Org.). A formação do cidadão produtivo: a cultura de mercado no ensino médio técnico. Brasília: Instituto Nacional de Estudos e Pesquisas Educacionais Anísio Teixeira, 2006. 372 p.

Um percurso de quase vinte anos resultou nesta publicação, organizada por Gaudêncio Frigotto e Maria Ciavatta, que o Inep lança neste primeiro semestre de 2006. A Formação do Cidadão Produtivo - a Cultura de Mercado no Ensino Médio Técnico apresenta uma coletânea de artigos que traçam um panorama sobre o tema dentro das décadas de 1980 e 1990. Aspectos conjunturais, políticos, tecnológicos, educativos, culturais, socioeconômicos, entre outros, são abordados pelos integrantes do Núcleo de Estudos, Documentação e Dados sobre Trabalho e Educação (Neddate) do Programa de Pós-Graduação em Educação da Universidade Federal 
Fluminense, que ainda contaram com o apoio do CNPq e da Faperj.

Da expansão do ensino técnico dos anos 80 à fragmentação da educação profissional dos anos 90, as mudanças de concepção nessa área aparecem nos artigos com uma visão da totalidade social, onde se destacam: a preparação para o mercado de trabalho, a globalização e a comparação entre a formação profissional nos países latinoamericanos e nos países desenvolvidos. A coletânea traça um paralelo entre essas mudanças no setor educacional e o contexto das transformações operadas pelo movimento ampliado do capital financeiro, a reestruturação produtiva e a nova organização do trabalho. Essas reestruturações passam pela elaboração da Constituição em 1988 e a nova LDB.

Que políticas públicas têm sido levadas adiante para responder às exigências do setor produtivo? Como se caracterizam as políticas educacionais da década de 1980 para o ensino médio técnico e como se distinguem das políticas implementadas na década de 1990? Considerando a presença ostensiva dos organismos bilaterais na definição dessas políticas, qual o sentido de suas ações? Estas são apenas algumas das dúvidas que os pesquisadores ousaram levantar ao longo da publicação. Não faltaram fontes de pesquisa. Com um certo caráter documental, A Formação do Cidadão Produtivo se baseou em 201 artigos selecionados em 13 periódicos nacionais publicados entre as duas décadas. Além disso, foram realizadas entrevistas com dirigentes e professores de Centros Federais de Educação Tecnológica (Cefets) e de Escolas Técnicas. O material foi reunido e dividido em três partes, com 15 capítulos no total.

Buscando questões mais amplas, da teoria e da história, a primeira parte carrega uma ambientação do estado da arte das políticas de expansão do ensino médio técnico e de fragmentação da educação profissional até à década de 80 . Na segunda parte, três capítulos expressam o movimento de travessia da sociedade, evidenciada pelo conflito de concepções e o jogo de forças que disputam a direção da sociedade brasileira em todos os âmbitos. A parte três refere-se à década de 1990, com oito capítulos em que se explicitam as mudanças na base material da produção com a tese da reestruturação produtiva, as reformas do Estado e as reformas educacionais, além de abordar a natureza da educação que forma o "trabalhador produtivo" para a nova base técnica da produção capitalista.

\section{Sobre os autores}

Gaudêncio Frigotto é doutor em Educação pela PUC-SP, professor titular associado do Programa de Pós-Graduação em Educação da Universidade Federal Fluminense e professor visitante da Faculdade de Educação da Universidade do Estado do Rio de Janeiro. É autor e organizador de diversas obras, entre elas A produtividade da escola improdutiva e Educação e crise do capitalismo real.

Maria Ciavatta é doutora em Ciências Humanas pela PUC-RJ, professora titular associada do Programa de Pós-Graduação em Educação da Universidade Federal Fluminense. É autora também de $O$ Mundo do Trabalho em Imagens - Fotografia como Fonte Histórica, entre outros títulos.

Os demais colaboradores de A Formação do Cidadão Produtivo são: Ana Lúcia Magalhães, mestre em Educação pela UFF; os doutores em Educação pela UFF Ana Margarida Campello, Marise Ramos, Ramon de Oliveira e Vera Corrêa; os doutorandos Francisco Lobo Neto, Jailson dos Santos, Laura Anita Handfas e Antônio Fernando Ney, da mesma universidade; e Eunice Trein, doutora em Educação pela UFRJ.

\section{Aline Adolphs Consultora - Inep}

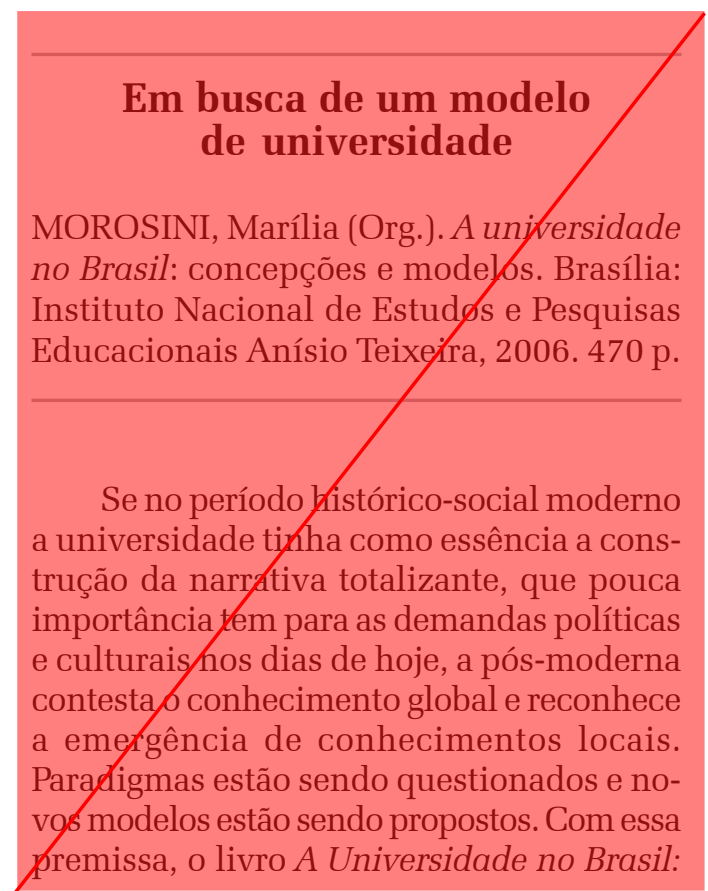

